\title{
Theatre for Development and Participatory Rural Innovation: Our Reflection on Enhancing Farmer Conscientisation through Participatory Development Practice in the Rwenzori Region, Western Uganda
}

\author{
Keneth Bamuturaki ${ }^{1 *}$, Oliver Schmidt ${ }^{2}$, Bernard Muhangi ${ }^{3}$, Grace Mary Mbabazi ${ }^{3}$, Robert Mawenu ${ }^{3}$, Paul Musobozi ${ }^{3}$,
} Christine Kobugabe ${ }^{3}$, Gilbert Van Stappen ${ }^{4}$, Xavier Gellynck ${ }^{4}$, Ir. Nancy Nevajan ${ }^{4}$, Joshua Wesana ${ }^{4}$, Benedict Sas ${ }^{4}$, Joanita Kataike ${ }^{3}$, Alex Rubalema ${ }^{3}$

${ }^{1}$ Kyambogo University, Kampala, Uganda

${ }^{2}$ Deutsche Gesellschaft für Internationale Zusammenarbeit-GIZ, Taunggyi, Myanmar, Burma, India

${ }^{3}$ Mountains of the Moon University, Fort Portal, Uganda

${ }^{4}$ Ghent University, St. Pietersnieuwstraat 33, 9000 Gent, Belgium

DOI: $\underline{10.36348 / \text { sjhss.2019.v04i11.008 }}$

| Received: 20.11.2019 | Accepted: 27.11.2019 | Published: 30.11.2019

*Corresponding author: Keneth Bamuturaki

\section{Abstract}

This article reflects on our experience of using participatory development processes to strengthen business practices of fish farmers in Western Uganda. We aimed to empower the fish farmers through collective participation so that they become critically aware of the realities that impeded the development of their fish farming enterprises, a process in Freirian terms described as conscientisation. We reflect on the challenges we encountered in our effort to foster participation and consequently conscientisation of the fish farmers, and the considerations that are important to make, when carrying out participatory agricultural development projects. We ask ourselves: how far did we go in achieving our avowed aim of engendering collective farmer participation. To what extent did we achieve an effective participatory agriculture development practice? We focus our reflection on our efforts at fostering collective participation in doing farmer participatory market research. We begin by exploring the literature related to the meaning of participatory development and conscientisation on one hand and the complexity of achieving community participation on other. We then explicate our effort at engendering participation during the farmer participatory market research process. We conclude the article with a critical reflection on our practice.

Keywords: Conscientisation, Participation, Empowerment, Development, Critical Reflection, transformation.

Copyright @ 2019: This is an open-access article distributed under the terms of the Creative Commons Attribution license which permits unrestricted use, distribution, and reproduction in any medium for non-commercial use (NonCommercial, or CC-BY-NC) provided the original author and source are credited.

\section{INTRODUCTION}

In 2016, we started implementing a two year South-North collaborative agricultural development project involving practitioners from Mountains of the Moon University (MMU) School of Business and Management Studies and Ghent University. The project aimed at strengthening business practices of small scale fish farmers in the Rwenzori region through a participatory rural innovation model. We aimed to empower the fish farmers through collective participation so that they become critically aware of the realities that impeded the development of their fish farming enterprises, a process in Freirian terms described as conscientisation. At the project design stage, MMU undertook resource mapping [1,2] and ascertained that the Rwenzori region had a great potential for a formidable aquaculture sector. From observational data along with our pre-project development survey of fish farmers, we estimated that about 700 fish farmers were active across the Rwenzori region but on subsistence or less commercial basis.

Seeking to ascertain how best we could intervene in the sub-sector, we conducted a constraints analysis and established that one of the major impediments to the growth of fish farming enterprises in the region related to a market development constraint [3]. From the analysis, we noted that this constraint was two pronged. First, there was the problem of lack of sufficient knowledge among many rural fish farmers about the available markets. Second, in cases where the markets were available, there was a problem of lack of sufficient quantities of fish produce to steadily sustain these markets throughout the year. This was aggravated by lack of access to financial resources to enable the farmers to transit from subsistence to commercial 
production and the fact that farmers accessed the available markets as individuals. Consequently, to remedy this key constraint, we set out to mobilise the fish farmers with the aim of not only strengthening their production capacity to enable them satisfy the available markets but also to empower them to collectively research, analyse and critically understand their fish farming enterprises.

In view of the contemporary paradigmatic shifts in agricultural support which emphasize the participation of farming communities in analysing, prioritising and taking action on issues which affect their lives [4-8], we aimed to implement a project which would bring the farmers at the centre of the process. We designated our approach as the Participatory Rural Innovation model. In designing the Participatory Rural Innovation model, we developed a community engagement model involving a fusion of Theatre for Development (TfD) and Enabling Rural Innovation (ERI) techniques. We believed that by drawing from both TfD and ERI practices, we had the propensity to trigger collective farmer participation and conscientisation.

By its very nature, TfD is a participatory performative process. Frances Harding, a scholar in African theatre at the London School of Oriental and African studies, defines $\mathrm{TfD}$ as 'a practice which enables communities, as stake holders in development, to participate by outlining their fears, needs and aspirations [9].' As a participatory process, TfD adopts an inside-out or development from with-in, endogenous or bottom-up approach as opposed to outside-in or development from without, exogenous or top-down approach [10-12].

Like TfD, ERI is a participatory learning approach which aims at placing farmers in the driving seat of working out what is good for their agro based enterprises. The ERI approach facilitates a critical exploration process in which members of the participating groups visualize their current situation, analyze their resources and collectively forge a better future. By making a fusion of theatre performance and ERI techniques, our engagement with fish famers would focus on collective empowerment, ensuring the participation of both men and women in participatory problem diagnosis and participatory market research.

Aware that participatory development can be a complex process $[13,8]$, in this article we reflect on the challenges we encountered in our effort to foster participation and consequently conscientisation of the fish farmers, and the considerations that are important to make, when carrying out participatory agricultural development projects. We ask ourselves: how far did we go in achieving our avowed aim of engendering collective farmer participation. To what extent did we achieve an effective participatory agriculture development practice? While our two years engagement with the fish farmers involved several activities such as training the project facilitation team, baseline survey and strengthening farmer group governance, in this article we focus our reflection on our efforts at fostering collective participation in doing farmer participatory market research.

In order to provide a theoretical context for our critical reflection, we begin by exploring the literature related to the meaning of participatory development and conscientisation on one hand and the complexity of achieving community participation on the other. We then explicate our effort at engendering participation during the farmer participatory market research process. We conclude the article with a critical reflection on our practice.

\section{Participatory Development and Conscientisation}

In the recent decades, participatory methods which aim to give the local community a more active role in planning, implementation and evaluation of projects have become common place in agricultural development [8]. In practice, participatory development seeks to shift the power over the development process from those who traditionally have defined the problems and the solutions (such as external donors) to those who are immediately impacted by the problems [5, 6, 1417]. It seeks to support people's participation in their development by enabling groups and communities to diagnose the problems they face, make well-informed decisions, mobilize for action, and assume responsibility for their own development [5]. The notions of mobilising for action and ownership of the development process reminisces Freire's concept of conscientisation.

The concept of conscientisation, so central to the participatory development process requires a clear explication. According to Freire, conscientisation means 'learning to perceive the social, political and economic contradictions of society and taking action against the oppressive elements of reality' [18]. It is the process in which 'men (sic), not as recipients, but as knowing subjects achieve a deepening awareness both of the socio-cultural reality which shapes their lives and of their capacity to transform that reality' [19]. The capacity to transform reality results from engaging the community in a process of 'dialogue, critical reflection and action - praxis' [18, 19]. Darder and her companions who have focused their research on critical pedagogy (learning in both formal and informal settings), define conscientisation as 'the process by which students as empowered subjects, achieve a deepening awareness of the social realities that shape their lives and discover their own capacities to recreate them' [20].

The concept of conscientisation was envisaged by Freire as a process that unfolds in stages namely; 
magic consciousness, naïve consciousness and critical consciousness [21]. Describing the worldview of people in magical consciousness, Freire notes that, "their interest center (sic) is almost totally around survival, and they lack a sense of life on a more historic plane... semi-intransitivity represents a near disengagement between men (sic) and their existence [21].' Turning to naïve consciousness, Freire argues that, '... it is characterised by an over simplification of problems; by a nostalgia for the past; by underestimation of the common man; by a strong tendency to gregariousness; by lack of interest in investigation...' [21]. As for critical consciousness, Freire notes that, 'it is characterised by: depth in the interpretation of problems; by the substitution of causal principles for magical explanations; by the testing of one's "findings" and by openness to revision...' [21].

The concept of conscientisation as envisaged in development practice should not be confused with consciousness-raising or awareness-raising. In this vein, Prentki and Selman observe, 'conscientisation goes beyond what is usually intended in consciousness raising, in that it includes not only awareness of reality..., but also a programme to change that reality' [22]. Whereas the end product of conscientisation as explained above is informed action upon critical reflection, consciousness-raising stops at 'enabling individuals and groups to see more clearly than they did before the nature of the social and cultural forces which impinge upon their lives' [22].

From the above it is evident that participation is at the core of the participatory development process. The members of the target community have to engage with the process in order to reach the required level of critical consciousness and action. However, participation in development projects is quite complex. What practitioners describe as participation in development has in most cases turned out to be a pseudo form of participatory practice. In the subsequent section, we analyse the problematic nature of participation.

\section{Participation and its abuses in Development Practice The Concept of Participation}

A number of scholars have delineated the meaning of the concept of participation in development projects [23-26, 17]. Nici Nelson and Susan Wright, both social anthropologists and community development practitioners describe participation as a means and as an end. As a means, participation is used to 'accomplish the aims of a project more efficiently, effectively or cheaply and as an end, participation entails that the community or group sets up a process to control its own development' [23]. Rahman, a renowned participatory development practitioner and scholar argues that participation in development should be spontaneous, implying that the 'process emerges out of the organic impulses of the communities, distinct from a process that emerges as a result of a discreet act of intervention by some external force with a conscious objective of promoting participation' [26].

Tufte and Mefalopulos working as World Bank consultants on participatory approaches to development have highlighted four levels of participation. These include passive participation, participation by consultation, participation by collaboration and empowerment participation [17]. Pretty [25] highlights similar ladders of participation to include manipulative participation, passive participation, consultative participation, material driven participation, functional participation, interactive participation and self-mobilisation. In passive participation, the people in the target community are simply told what will happen or has already happened. They do not have any input in the development programme [24]. Participation by consultation is an extractive process where target communities answer questions posed by outside researchers or development experts. Decision-making is kept in the hands of external professionals who are in no way under obligation to incorporate the community's input [17]. Participation by collaboration is where selected groups of people in the identified community discuss and analyse predetermined objectives set by the project [17]. Functional participation is where 'people participate by forming groups to meet pre-determined objectives related to the project and such involvement tends to occur after major decisions have been made' [24]. In empowerment participation, similar to Pretty's notion of interactive participation, 'the members of the target community are viewed as capable of initiating the process and taking part in analysis of development goals which leads to joint decision-making [24].'

Of the levels of participation delineated above, empowerment or interactive participation is the most applicable to effective participatory agricultural development practice. According to [27] manipulative participation, passive participation, consultative participation and material driven participation are unlikely to have a positive and lasting effect on the participants' lives. Schneider \& Libercier [28] similarly write that consultation should no longer be viewed as participation, nor implementation of activities defined by external actors.

Effective participation in development programmes requires practitioners to be cognisant of the need to balance the power related dynamics [29]. As such participation in a development project should encourage egalitarian dialogue among participants, or horizontal communication $[30,31]$. This means that, all participants are given the opportunity to communicate on an equal level, regardless of their respective status or role $[32,33]$. By taking this approach, those most affected by issues can seek joint solutions which leads to local ownership [30, 17]. This leads to local 
ownership which entails that the development or social change process should be driven by the participants, or those directly affected by the initiative, rather than solely by external bodies [34, 17].

\section{Abuses of Participation}

A number of participatory development critics have indicated that participation is a term which can be potentially abused $[35,36,8,37,25,38]$. For instance, Plastow observes that 'the concept of participation has recently been problematised in development studies and needs not to be taken at face value' [37]. Linje Manyozo notes that 'in both tokenism and nonparticipation, participation is integrated as a rubber stamp or letterhead strategy where powerful elites deliberately distort participation to "engineer" community support for irrelevant programmes and policies' [36]. Expounding on the problematic nature of participation, Chinyowa reveals that:

In both contemporary educational and development discourse, the idea of participation is increasingly being regarded as falsely leading to an erroneous interpretation of the social construction of reality by dominant groups with the people's transformation. The strategies being deployed in the name of participation such as dialogue, giving voice, conscientisation and empowerment are deemed to create the illusion of liberation while they reinforce prevailing oppressive structures [39].

Majid Rahnema describes participation as a 'modern jargon that uses stereotyped words to support the most fanciful constructions which are ideal for manipulative purposes' [27]. Elsewhere Rahnema is critical of participation especially if it adopts an interventionist approach. He argues that:

Participation which is also a form of intervention is too serious and ambivalent a matter to be taken lightly or reduced to an amoeba word lacking in any precise meaning, or a slogan, or fetish, or, for that matter, only an instrument or a methodology, reduced to such trivialities, not only does it cease to be a boon, but it runs the risk of acting as a deceptive myth or a dangerous tool for manipulation [40].

Rahnema implies that such participation has implications relating to power relations and impacts negatively on the oppressed or marginalised sections of the community. In Rahnema's view:

When A considers it essential for $\mathrm{B}$ to be empowered, A assumes not only that B has no power-or does not have the right kind of power-but also that A has the secret formula of a power in which A has to be initiated [40].

Robert Chambers argues that 'Participation may be used as a cosmetic label, to make whatever is proposed appear good' [35]. As a cosmetic label in development proposals, 'donor agencies and governments require participatory approaches and consultants and managers say that they will be used and then later that they have been used while the reality has often been top-down in a traditional style' [35]. Elsewhere, Chambers [9] substantiates that participation has been 'disembedded' from its sociocultural roots and perceived as a 'thing', 'object' or 'resource' for keeping the market economy alive. The notions of 'keeping the market economy alive' and cosmetic label coined by Chambers above relate to the money element associated with discourses of participatory development. Projects that claim to foster participation in modern times attract a lot of funding from the neoliberal world. Players in the field of development, in most cases, articulate in their application for funding proposals an aspect of participation aimed at empowerment. The major question, however, is whether the aims of participation are thereafter adhered to and achieved in practice. Pondering on this question, Doho argues that 'in most cases local communities seem to have been used as "guinea pigs" and not as veritable practitioners ...' [41]. The phrase 'guinea pigs' used by Doho points to the fact that sometimes people who claim to be participatory development practitioners and the commissioning bodies themselves have ulterior intentions-different from working closely with the communities - to engender a process of people centred development. For example, it is true that some people get involved in development practice to earn a living, not necessarily because they aim to improve communities, while in most cases commissioning bodies are not after the quality of the process but about the statistical indicators of projects' success such as the number of people who attended the community sessions and are believed to have picked the message [42].

\section{Fostering Participation - Farmer Participatory Market Research}

Farmer participatory market research was the second phase of the larger fish farmers project after a baseline survey. Unlike the baseline phase in which we used traditional methods of research to gather information concerning the fish farming enterprises, in the farmer participatory market research phase we deployed our participatory rural innovaton model. We aimed to empower farmers to be able to collect market information which they would use to strengthen their fish farming enterprises. Instead of engaging all the 60 farmers we had mobilised in each district, we worked with a marketing team of 10 farmers from each district. Together with farmers the facilitators identified four local markets in each district which were to be visited. The participatory market research process lasted for three days in each district. In the sections that follow, we discuss our effort in implementing our participatory rural innovaton model to empower the farmers to do participatory market research. 


\section{First Community Workshops- Building Community Cohesion}

Clifford and Hermann have posited that, 'for the identity of the group to be one of power, the group needs to have control over the decision making process and experience the responsibility which exists with this role' [43]. This means that in participatory development processes, facilitators should make effort to build formidable groups. Consequently, we began our community engagement process with building community cohesion. We aimed to diffuse social barriers to enable participants work together. For this reason, every first community meeting in each district was meant to build a rapport between the facilitating team and the participating fish farmers. Patrick Mangeni [12] and Chinyowa [44] have recognised the importance of games and collective activities as key to group building. Chinyowa [44] suggests that games provide a recipe for participants to share and build trust in each other. Drawing from this understanding, our first community workshop activities with fish farmers would always start with collective activities aimed at freeing the participants so that they could express themelves. Acting as facilitator-participants, we led the groups into games such as the blind leading and name on paper [43].

In the blind leading game, everyone was asked to find a partner and label each other A and B. All As closed their eyes and the Bs gently took their hands so that there was a point of contact between them. In silence, the Bs moved the As around the compound taking care not bump into anyone or anything. When B felt that A was fine, they would speed up, and explore the possibilities more, always putting A's safety first. After a few minutes, the Bs would bring the As to a halt. There would be a change over in the roles so that A led B. Participants shared their experience of blind leading someone and of being led.

In the name on paper game, participants maintained their position in a circle. A large sheet of manila paper and marker pens were put in the centre of the circle. Participants were invited to volunteer in turns to write down their own name on the manila paper and then speak to the group about it based on points such as what it means, if they have a nickname and a story connected to it. As facilitator-participants, we volunteered to write our names first and talk about it. For example, leading this game one of the facilitators said, "my name is Keneth; it was given to me by my parents when I was a baby. My parents named me after St Keneth, a man who evangelised in Northern Ireland and Scotland." The participants continued after his example and this was continued until all the participants had shared their name. The name and paper game facilitated an effective process of self-introduction. After the game we all got to know each other and immediately started referring to each other by name.
After each game, participants were invited to give feedback to the group about their experience. This would usher in moments of reflection. For example, when the participants were invited to tell their experience after the blind leading game, they variously responded, "I felt so good, I felt as if I was flying in the air, I felt I was being trusted, it was full of fun . . ." These moments of reflection inspired the participants to begin expressing themselves.

In all our first community workshops, we made effort to help the fish farmers to know the goals of Mountains of the Moon University, the facilitating organisation and to understand our Participatory Rural Innovation model. We aimed to provide participants with enough information to enable them decide if they wanted to actively participate in the programme and to understand the process and the ground rules of the programme. We used the first meetings with the fish farmers to initiate a dialogical interaction. We endeavoured to know the different farmers groups and to understand their characteristics, their history, goals, activities, membership, organisational structure, constitution and registration. We sought to understand what the groups have achieved. We invited members to ponder on the concept of fish farming as a business, to understand that farming as a business means producing what one can sell, rather than sell what one has produced. We highlighted the issue of participation noting that our programme encourages participation of women and men on a subject to subject or a horizontal plane of power relation.

\section{Levelling expectations - the Agaba and Mugisha Story}

Since our programme was meant to empower the farmers to take the development of their enterprises in their own hands rather than expect hand-outs from the facilitating organisation, we made effort at every first community meetings to level the expectations of the participants. We engaged farmers in interpreting a graphic/pictorial presentation of a story involving two families - the Agaba family and the Mugisha family. The two families in the story always presented two contrasting situations. On one hand, when the Agaba family were invited to a Participatory Rural Innovation meeting, they pulled out of the programme because the facilitators have not promised hand-outs in form of cash and inputs. Because they refused to engage in a collective empowerment process with the farmers, they reaped low returns from their enterprise. On the other hand when the Mugisha family were invited to the Participatory Rural Innovation, they cooperated with the animators and the rest of the community even when they were informed that the programme would not involve donation and hand outs. They were empowered by the collective empowerment process which enabled them to grow their enterprise and fetch better prices on the market. 
After interpreting the story, farmers would be facilitated through a collective reflective and dialogical process. The dialogue would focus on the questions drawn from the story: What do you learn from the story? What is the difference between the two groups? What do you expect to get from the facilitating organisation? What should you expect from the programme? Was it good for Agaba to remain silent about his expectations at the first meeting? Why did Agaba and his friends leave the meeting? What were the consequences? What did Mugisha and his friends learn from the trainings? How does this help them?

The ensuing dialogue on the above questions would be transformative. From the reflective discussion on the Agaba and Mugisha story, participants would conclude that it is not sustainable to be given free things always. Farmers must to know how they can access and get what they need rather than someone else feeding them. In kakabara, kyegegwa district, one of the participants sumed it up saying, "it is good to be taught how to catch the fish than someone giving you fish every day. This means that even if she/he is not there you can afford to eat the fish on your own.' Most of the participants said had experienced similar situations where they are feed/carried by donor agencies but after sometime, when the projects ended and the carrying stoped, they get into real problems.

\section{Dramatic Visioning of the Fishing Farming Enterprise}

In all our engagement, we would involve the farmers in a dramatic visioning process to empower the farmers to see clearly the potential embedded in their fishing farmer enterprise. The facilitators would work with the farmers to rehearse and perform a river code role drama. In creating the river code role drama the facilitator and farmers would agree on the materials they would use. The materials would be drawn from the community's immediate environment. This was meant to empower the farmers to understand that they can use the very resources in the milieu of their community to engage in a reflective process on issues which affect their lives. The groups would agree to prepare two pieces of white rope to represent the banks of a river and some stones or papers to represent stepping stones in the river. Then the group would identify a good place where the role-play would be performed. In most cases, the groups identified an outdoor setting for the roleplay, usually under tree shades so that the actors could perform while the rest of the group observes. The facilitator together with the actors would sketch a river on the ground using ropes.

The two lines would be drawn fairly apart to represent the banks of a river. In the river, circles would be drawn to represent stepping stones and an island in the middle of the river. The stepping stones would be placed at a relatively calculated distance so the actors can easily step from one to the next. Three farmers (preferably of the same sex, whether men or women) would be asked to volunteer for the river code role-play. Away from the group, the facilitator and the actors would discuss the role-play and practice it until the actors fully understand their roles. During the performance, the farmers would be invited to watch the role play carefully. In the photographs below, the farmers are rehearsing the river code drama.
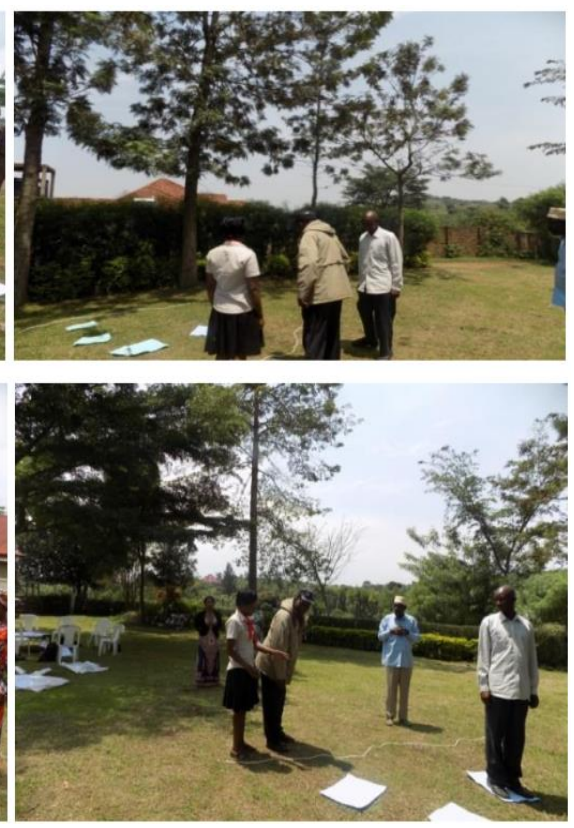

strong. A third person (C) comes along and sees their difficulty. $\mathrm{C}$ leads them up the river and shows them the stepping stones. $\mathrm{C}$ encourages them to step on the stones but they are both afraid, so $\mathrm{C}$ agrees to take $\mathrm{A}$ on

\section{The performance of the role play would be as highlighted below:}

Two persons (A and B) arrive to the river. They are discussing how to cross. The current is very
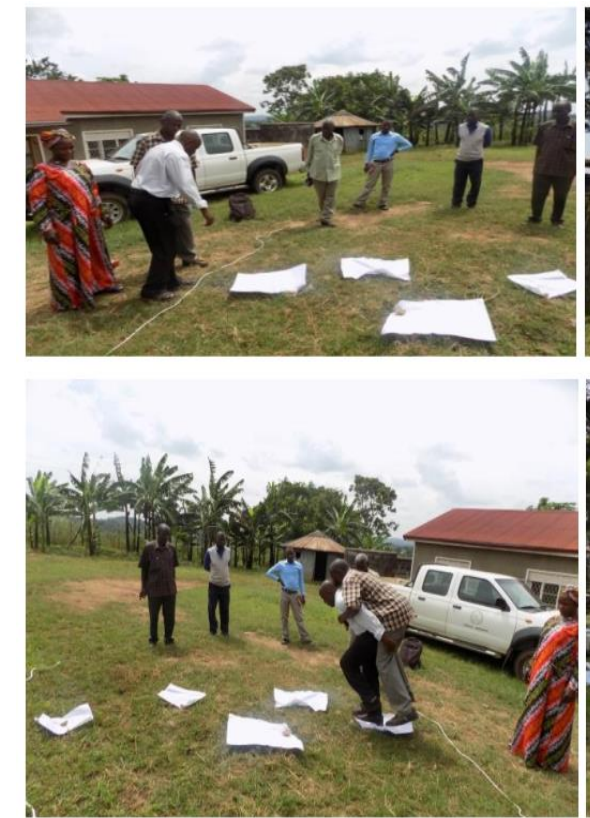

(n) 
his back. By the time $\mathrm{C}$ gets to the middle of the river, he has become very tired, so he puts $\mathrm{A}$ on the little island. C goes back to fetch B. C asks if B wants to be carried. B refuses, since she has seen what happened to A. $\mathrm{C}$ gives $\mathrm{B}$ the option to guide her through the river. B accepts. C takes B's hand and encourages her to step on the same stones herself. Halfway across the river, $\mathrm{C}$ lets go of B's hand. B starts to gain confidence and manages to cross alone. When they get to the other side of the river, they are both extremely pleased with themselves and they walk off together. A tries to get their attention, but $\mathrm{B}$ and $\mathrm{C}$ have already walked off happily.

After the performance, the facilitators would lead the groups through a reflective dialogical process by asking thoughtful questions based on the role-play: What did we see happening in the play? What different approaches were used by the two people to cross? What are the advantages of being carried? What are the disadvantages of being carried? What are the advantages of being guided? What are the disadvantages of being guided? Which method would you prefer? What does each side of the river represent?

In the reflective dialogue, two contrasting scenarios would always emerge. In the first scenario, the service provider is carrying the farmer. The farmers in most cases would decipher from this act a service provider who does everything for the farmer, including giving free inputs like seeds or making decisions for the farmer. However, after some time the service provider gets tired of carrying and drops the farmer. The farmers would understand that in reality, this can happen when a project ends and the farmer is left alone, without a clear vision of how to get to the other side. In the second scenario, the service provider empowers the farmer by guiding them through the river instead of carrying them. The farmers would analyse this as the service provider who supports the farmer to make use of the stepping stones. As such, the farmer learns how to cross the river all by themselves, without the help of the service provider. This would imply that even if the service provider has to leave at some stage, the farmer will have all the knowledge and skills to cross the river independently. It would become apparent that one side of the river (the starting point of crossing) is current situation of the farmers, while the other side (the destination) represented the farmers' desired situation in the future. It would also become clear that the river represented the challenge the farmers were facing and the journey through the river represented the work the farmers have to do to achieve their goal of getting to the desired situation. The facilitators and the group would conclude their reflective process by thinking about the stepping stones in their community that can help them to cross to the desirable situation. They would think about natural, human, social, financial, and physical resources.

\section{Crossing the River: Farmer Participatory Market Research in Kabarole and Kyegegwa}

Having theatrically visualised and analysed the fish farming enterprises through the river code drama as discussed above, the fish farmers would visibly be empowered to develop their businesses. The farmers from various districts engaged in the project would be determined to improve on their practices and expand their capacity by digging more ponds. In the river code drama parlance, they would be empowered to cross the river - to use the stepping stones in the river to move from the undesirable state of poverty to prosperity. In the post-performance analysis above, the farmers working together with the facilitators resolved that before they could expand their enterprises, they had to be sure that there would be enough market for their fish produce.

In Kabarole and Kyegegwa districts, after dramatic visioning and post-performance analysis, the farmers resolved to research into the fish produce market dynamics. Together with the facilitators, they resolved to engage in a collective creative process of farmer participatory market research. In this process, farmers visited fish markets in their community to gather from the traders crucial market information. In Kyegegwa district, farmer participatory market research was done in Kakabara and Kyegegwa town council, while in Kabarole it was done in Kabarole Municipality and Bunyangabu Sub-county. During the farmer participatory research workshops, facilitators engaged the participants in games and exercises which would act as ice breakers to enable the participant to get ready to work together.

In preparing for the process of farmer participatory research, the facilitators together with the fish farmers agreed on the questions which would be included in the market research checklist. The questions in the farmer particiatory market research checklist sought information relating to the species of domestic and export fish traded in, seasonal changes and how they affected the fish farming business, species which fetch the highest and lowest margins, species most traded in, sources of fish produce, marketing and operational costs, sources of market information, methods of setting fish market prices, storage and packaging modalities and the challenges fish traders face among others. On the day of market visits, farmers met the fish traders at their stalls and used an interview schedules to elicit discussions on the above issues. In the photographs below, farmers are engage in participatory market research process. 

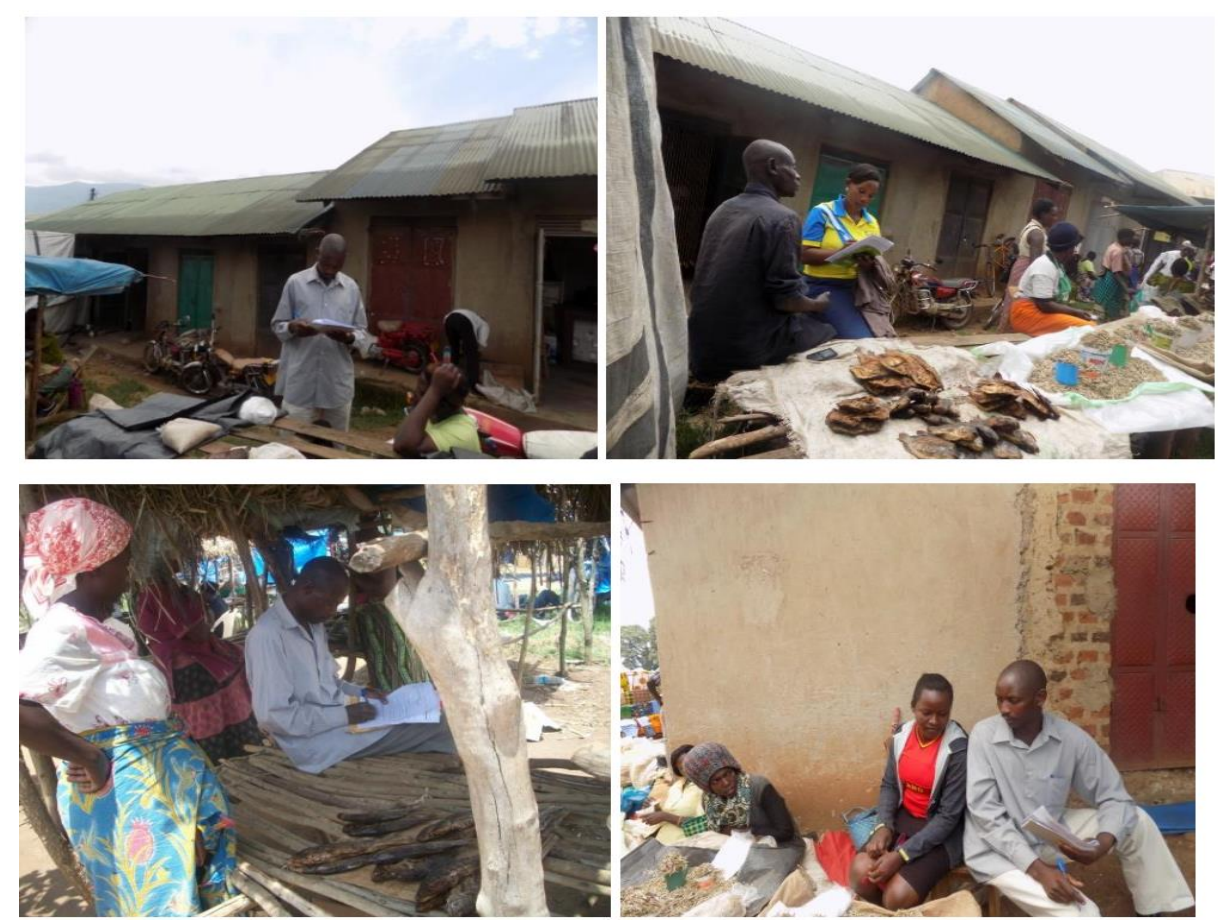

The process of farmer participatory market research in both Kabarole and Kyegegwa districts produced identical expriences and was transformative for the farmers. In the subsequent section, we examine the extent of conscientisation fostered by collective creative process of farmer participatory market research.

\section{Emerging Critical Consciouness}

After the participatory market research process, farmers were facilitated to reflectively analyse

and discuss their findings focusing on: name of the market visited, type of fish sold most, main source of income for the traders, main customers of the fish, source of the fish, the process of pricing, the trader's plan to expand their businesses, the ability by the farmers to do the market research activity the advantages of engaging in the participatory market research activity and how the farmers would use the information obtained to bolster their businesses. In the photographs below, farmers are engaged in post market visit dialogue and analysis.
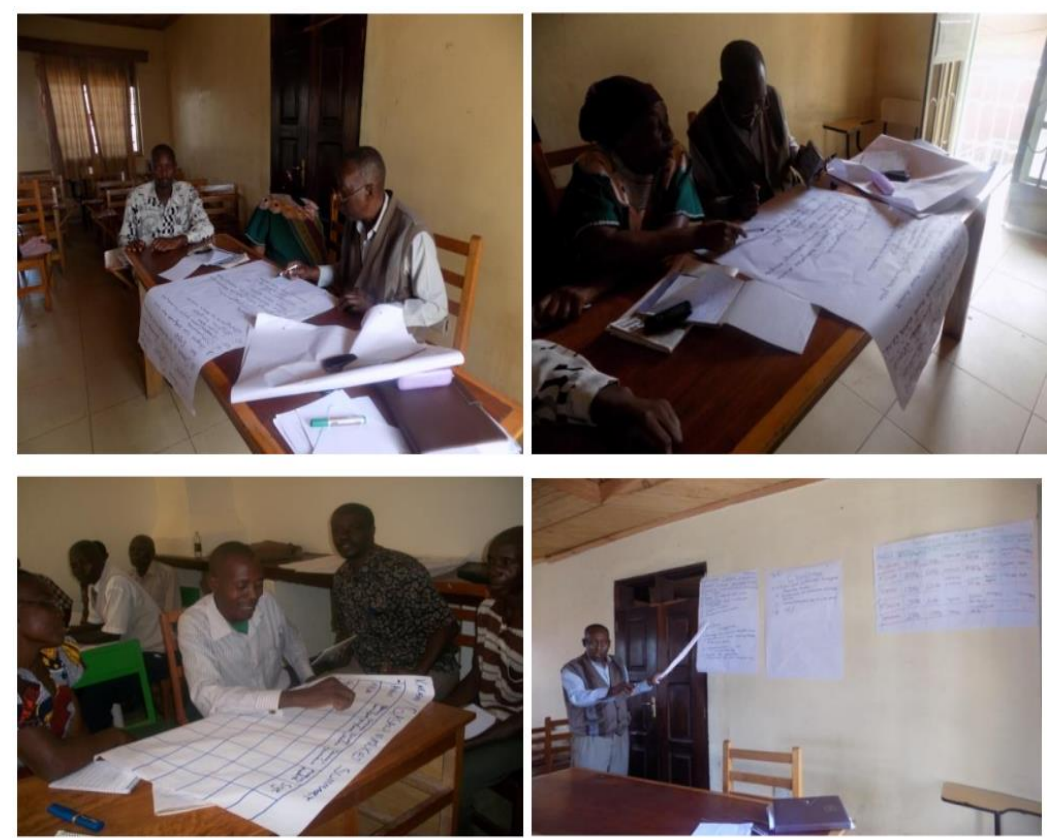


\section{From sharing and analysing market information, the farmers discovered that:}

- Ngege or Tilapia, Mukene and Mputa were the main species of fish sold in the market;

- All the fish was obtained from lakes and availed to the local traders by middle men;

- Local people and hotel operators were the main customers of fish;

- Fish trade was the main source of income for the traders;

- The traders were considering expanding their businesses.

Based on these findings, the farmers were resolved to strengthen their groups so that they may increase production. They noted that the participatory market research process had been rewarding and empowering since, they were able to know the species of fish most wanted on the market, the demand of fish as shown by the amount of fish sold, the pricing process and the sources of the fish. They also noted that if they were to capture the market, they needed to ensure good quality of fish using effective methods of food preservation such as salting, smoking and sun drying.

During the discussion and sharing of feedback, the farmers reflected on key findings. They noted with great concern that two species of fish namely Emale and Semutundu were scarce on the market. They emphasized that Emale was one of the two main species of fish farmed in ponds in Uganda but was lacking on the market. They concluded that there would be a lot of potential in their fish farming businesses especially if they concentrated on getting the Emale and Semutundu species to the market. The farmers were pleased to discover that much of the fish in the market was obtained from lakes by middle men. The farmers concluded that there was generally high demand for fish in their local areas and were inspired to produce in large quantities. They argued that if they produced fish in large quantities, they would be able to strengthen their competitive advantage over the middle men.

The sharing of the market research experience was graced by the attendance of the district fisheries officer (DFO). Empowered by the market visit experience, farmers addressed some points of action directly to the DFO. They for example inquired whether the DFO would be able to advise them on the right sources of fish seed. The district fish farmers' association chairman pledged to convene a meeting to discuss how the farmers would strengthen their groups. The farmers themselves requested for training in business planning and record keeping. They noted that they had a big problem of lack of fish nets arguing that some of them were using mosquito nets to fish their ponds. Empowered by the participatory process the farmers requested MMU to offer them training in business planning and record keeping. Thus far, our participatory process with the communities had fostered farmers' increased awareness of their fish farming enterprises and the fish farmers were beginning to move from the level magical consciousness to critical consciousness.

\section{Discussion and Reflection: Implications for Future Practice}

Though we have argued that our participatory market research process transformed the fish farmers from the state of magic consciousness to critical consciousness, it is vital that we reflect on what should have been done better to foster a deepened process of conscientisation. Reflecting on our practices, we recognized more could have been done to make our participatory process more engaging and transformative. In the subsequent sections, we discuss the key flaws in our practice.

\section{Flawed process of Problem Diagnosis/Absence of Participatory Research \\ An effective participatory development} process should enable facilitators and the participants to engage in collective problem analysis $[5,6,8]$. Our first and foremost constraint in our effort to foster an effective participatory development process with the fish farmers was lack of real problem diagnosis through participatory research. From the onset of our work, the farmers were not afforded ample space to define their needs through collective problem diagnosis a process in Freire's terms described as thematic investigation. From the inception, it is the facilitating team's perspective of the farmers' development needs which took focus.

In participatory development practice, practitioners and scholars draw from Freire's critical pedagogy theories, especially the notion of problemposing education to foreground the participatory research methodology as key to problem analysis in target communities [18, 19, 21, 45]. According to Byam, prolific TfD scholar, 'this type of research is contrary to traditional research paradigms in that the participants are also the subjects and the teachers hold no elite distinction while gathering information through their active involvement in the community' [46]. Describing it as emancipatory action research, Margaret Ledwith, a critical community development scholar argues that, 'it is rooted in dialogue, attempting to work with, not on people and intends that its process is empowering for all involved. More than this, it is committed to collective action for social change as its outcome' [47].

In our practice, what should have been a collective problem analysis process with the farmers was replaced with a traditional baseline survey. Instead of adopting a participatory research paradigm, we used an extractive research process aimed at obtaining information from the fish farmers relating to their fish farming enterprises. The facilitating team, sitting at their Mountains of the Moon University headquarters 
designed a nineteen page research instrument to gather the information. The instrument focused on evaluating the financial literacy knowledge levels, market information access, record keeping, value \& supply chain $\&$ business plan knowledge of fish farmers in the Rwenzori region. After designing the questionnaire, we trained research assistants in the traditional process of gathering information and deployed them in the various districts of Rwenzori district to interview the farmers. In so doing, as Ledwith [47] would put it, we were researching on the fish farmers instead of researching with the fish farmers about the problems affecting their fish farming enterprises. Furthermore, at the project design stage we used data from our 2015 survey and prescribed what we thought were the constraints of the fish farmer sector in the Rwenzori region. In so doing, we ignored Chambers' advice that 'in using the research to generate change, the point is that participants should take the lead in determining the strategy and the researcher's role it... No longer is the purpose of research to extract information from the poor and subordinated ...' [35].

Reflecting on the nature of participation in the project, we noted that our work exhibited models of participation discussed earlier in this article, which have been described in modern development practice as tokenistic, manipulative and extractive. We noted that our work was from the onset interventionist and prescriptive. Instead of foregrounding a process in which the farmers could take a central role from the inception of the project, it is the project facilitating team which took the centre. As Doho [41] would put it, the farmers were used as guinea pigs of an extractive research process. As a facilitating team, we were from the very beginning of our project more interested in knowing about the weaknesses/development needs of the farmers and thereafter intervene in their needs. Typical of Rahnema's [40] concept of interventionist participation, it was as if we wanted to prove to the farmers that we had the knowledge power and formula of transforming them.

The appropriate way of engaging the communities should have been to involve the farmers in the process of telling their unique stories about their fish farming enterprises using participatory research processes such verbal storytelling, image theatre, body imaging and participatory photography among others. This would have enabled the farmers to see clearly the contradictions impeding the growth of their fish farming businesses. Commenting on the significance of story in participatory development, Prentki advises that:

The story is the archive of the individual, the family, the community; the means by which the experience of living is made intelligible. If the NGO worker enters the community researching for issues and problems, or, worse, with a pre-set agenda of issues which the organisation has deemed important, there is an immediate distortion of experience [...] [22].

As a cultural process, storying would have facilitated the exploration and unveiling of contradictions beneath the economic oppressions of the fish farmers. As Prentki observes, 'when the members of the community tell their stories, the consequence is likely to be that contradictions will emerge, reflecting sectoral interests; one story will be countered by another as different realities contend for attention' [22]. If this had been done in our practice, it would have fostered a deepened process of human transformation among the fish farmers.

\section{Thinking about the notions of "Sustainability" and "Time"}

In participatory development practice, "sustainability" and "time" are two different but closely related concepts. Sustainability relates to the extent to which the target community is empowered to continue with the development process even after the animators have left the community [48]. The concept of time relates to the length of period which has been allowed for the development process to get imbued in the community. Principally, participatory development processes need an ample amount of time to take root and be owned by the beneficiaries of the development project. When ample time is given to a participatory development process, the community becomes imbued in the process, ensuring the possibility that the process of empowerment will continue even after the animators of the process have left.

Writing about participatory development practice, Isgren observes that, ' $\ldots$ the process is often slow, especially the early phase where new relationships and trust have to be built up between the different actors' [49]. Isgren's observation suggests that enough time has to be allowed for community engagement to take shape and for the process to grow into an effective empowerment encounter. In most cases, as the case was with us, the facilitators go the community as visitors. Therefore, an ample amount of time is required to allow a trusting relationship to developed between the facilitating team and the community. Conversely, commenting on participatory development communication Tufte and Mefalopulos, argue that 'this model of engagement and bottom-up communication takes time to implement and runs counter to prevailing institutional systems governing the allocation of development assistance funding' [17]. To make sense of Tufte and Mefalopulos' point, funders always require that a development project be completed in a specified period of time.

In our experience with the fish farmers project, we later realised that the general set up of the project with several activities to be implemented in a period of only two years meant that there was not enough time to 
allow a sustained engagement of the communities in analysing issues. We began our community engagement with our "rushed" extractive research process, highlighted above in all the six districts covered by the project. We say rushed because we spent four days in each of the districts. At the centre of the extractive research process were research assistants whose interest was in interviewing as many farmers as possible. This means that there was no sufficient care taken to build a useful rapport with the farmers during our initial contact with the community. After the research, we immediately moved on to farmer participatory market research, a process which took only three days in each of the districts. In our practice with the farmers, we could feel it that the farmers viewed us visitors as "officials" - that is, powerful men and women from the university. Such suspicion could not foster effective ownership of the project.

The idea of investing ample time in a participatory development process relates to the theoretical foundations of the process of conscientisation or empowerment. Commenting on the empowerment process, Darder et al., argue that 'it is a recurrent, regenerating process of human interaction that is utilised for constant clarification of the hidden dimensions of reflections and actions' [20]. Similarly, Blackburn notes that, 'rather than seeing empowerment as a goal or an endpoint, it may be more useful to regard it as a state of mind: an on-going encounter with reality, which is itself permanently changing' [51]. So, in order to achieve an effective process of conscientisation, we needed to have a sustained engagement with the community beyond just three days as the case was with the farmer participatory research process.

Closely related to the notions of sustainability and time is the issue of the geographical extent in which we implemented our work. As already noted we did our work in a large geographical area covering the six districts of the Rwenzori region. On the contrary, effective participatory projects focus on small manageable geographical areas. In practice, it is projects which adopt the dominant/modernisation model which tend to focus on expansive areas because of their tendency to diffuse information and technologies [52]. As a result of operating in large geographical expanses, we could not have enough time to engage the farmers in a sustained participatory process of analysing issues that affect their lives. This is because our engagement with the farmers involved oneoff or ephemeral engagements in our haste to move to the next community. Reflecting on the extent of our work, we noted that our approach was quantitative rather than qualitative, because our success was measured by the number of districts we were able to tour and influence, and not by how the process had been critically engaging and sustainable. Operating in a large geographical expanse was brought about by our effort to fit in the prevailing politics of funding. At the project design stage, we were conscious that our funder, VLIROUS preferred projects which benefit people in the area covering the six districts of the Rwenzori region. Whereas VLIR-OUS could have accepted our proposal to focus on a small manageable geographical area, we sought to be as faithful as possible to this requirement.

\section{CONCLUSION}

By and large, this article has shown that participatory agricultural development processes can be an effective means of engaging communities on pertinent issues in their enterprises. By deploying a participatory rural innovation model, we enabled fish farmers to visualise the potential in the aquaculture sector. The process of visioning empowered the farmers to engage in a collective process of finding market information. After the participatory market research process, the farmers through collective analysis made sense of the market information. Having noted from the analysis that Emale and Semutundu fish species were scarce on the market, the farmers were collectively empowered to produce these species on large scale. So, participation in learning the market dynamics had triggered some level of conscientisation. Farmers were able to make key enterprising decisions for their aquaculture enterprises. However, this article has also indicated that participatory agricultural processes can be easier said than done. Our practice indicated that effective conscientisation through participatory development processes can be achieved when the communities are brought at the centre of the process from the inception. This can give them opportunities of inner transformation and empowerment to the extent that even those farmers with long muffled voices can begin to speak and express their voice. To achieve this, the facilitator has to structure the process in such a way that the power to create and the means of production are transferred to the participants. It requires flexibility on the part of the facilitators, effective judgement and appropriate decision making skills. For future practice, it will be vital for MMU to structure a process which will engage the farmers through the process instead of the traditional approaches to research which our practice adopted.

\section{ACKNOWLEDGEMENT}

The writing and publication of this article was funded by VLIR-OUS, a Belgian international development organization through its support to Mountains of the Moon University for the project titled Strengthening Business Practices of small scale fish farmers in the Rwenzori Region. This work was published in the Consciousness Literature and the Arts Journal under the title Enhancing Farmer Conscientisation through Participatory Development Practice: Our Experience with Participatory Market Research in the Rwenzori Region, Western Uganda. Consciousness Literature and the Arts Journal permits 
authors to maintain ownership of copyright and republish work elsewhere with acknowledgement.

\section{REFERENCES}

1. MMU. (2015). Survey of practices and training needs of fish farmers in the Rwenzori region, compiled by Martin Sserwadda, IV.2015, Fort Portal (unpublished). Fortportal.

2. VLIR-OUS. (2014). Joint Context Analysis Uganda. Retrieved from http://www.vliruos.be/media/6401812/ouganda.pd $\mathrm{f}$

3. Schmidt, O., \& Sas, B. (2017). Strengthening business practices of small scale fish farmers, Call TEAM projects and South Initiatives 2017. Fortportal: VLIR-OUS.

4. Altieri, A. (2005). An agroecological basis for natural resource management among poor farmers in fragile lands. In J. Gonsalves, T. Becker, A. Braun, D. Campilan, H. DeChavez, E. Fajber, ... R. Vernooy (Eds.), Participatory Research and Development for Sustainable Agriculture and Natural Resource Management: A Sourcebook. Volume 1: Understanding Participatory Research and Development (pp. 41-50). Laguna, Philippines and Ottawa: International Potato Center and International Development Research Centre.

5. Bessette, G. (1996). Development Communication in West and Central Africa: Toward a Research and Intervention Agenda. In G. Bessette \& V. C. Rajasunderam (Eds.), Participatory Development Communication: A West African Agenda (pp. 936). Ottawo, Canada: International Development Research Centre.

6. Bessette, G. (2004). Involving the Community: A Guide to Participatory Development Communication. Ottawo, Canada: International Development Research Centre.

7. Goma, H. C., Rahim, K. ., Nangendo, G., Riley, J., \& Stein, A. (2001). Participatory studies for agroecosystem evaluation. Agriculture, Ecosystems \& Environment, 87(2), 179-190.

8. Mohan, G. (2008). Participatory development. In: Desai, V., \& Potter, R. (eds.). The Arnold Companion to Development Studies, 2nd ed. London: Hodder, 49-54 Mosse,. In V. Desai \& R. Potter (Eds.), The Arnold Companion to Development Studies (2nd ed., pp. 49-54). London: Hodder.

9. Chambers, R. (1997). Whose Reality Counts? Putting the Last First. London: IT Publications.

10. Chinyowa, K. C. (2009). Play as Aesthetic in African Theatre for Development. Saarbrucken: Lambert Academic Publishing.

11. Epskamp, K. (1989). Theatre in Search for Social Change: The Relative Significance Of various Theatrical Approaches. The Hague: Centre for the Study of Education in the Developing Countries (CESO).

12. Mangeni, P. (2007). Negotiating Gender Through
Theatre for Development. PhD Thesis: Griffith University.

13. Mayoux, L. (1995). Beyond naivety: Women, gender inequality and participatory development. Development and Change, 26(2), 235-258.

14. Boeren, A. (1992). Getting involved: communication for participatory development. In A. Boeren \& K. Epskamp (Eds.), The Empowerment of Culture: Development Communication and Popular Media. The Hague: Centre for the Study of Education in the Developing Countries (CESO).

15. Dragon, G. A. (2001). Making waves: Stories of Participatory communication for Social Change. A Report to the Rockefeller Foundation. New York: Rockefeller. Retrieved from http://www.ncbi.nlm.nih.gov/pubmed/23522048

16. Duraiappah, A. K., Roddy, P. ., \& Parry, J. E. (2005). Have participatory approaches increased capabilities? International Institute for Sustainable Development (IISD), June 2005.

17. Tufte, T., \& Mefalopulos, P. (2009). Participatory Communication: A Practical Guide: A World Bank working papers. Washington DC.

18. Freire, P. (1970). Pedagogy of the Oppressed. London: Penguin Books.

19. Freire, P. (1972). Cultural Action for Freedom. Middlesex: Penguin Books.

20. Darder, A., Baltondana, P. M., \& Torres, D. R. (2003). Critical Pedagogy: An Introduction. In A. Darder, P. M. Baltondana, \& D. R. Torres (Eds.), Critical Pedagogy Reader (pp. 1-24). New York: Routledge Falmer.

21. Freire, P. (1974). Education: The Practice of Freedom. London: Writers and Readers Publishing Cooperative.

22. Prentki, T., \& Selman, J. (2003). Popular Theatre and Political Culture: Britain and Canada in focus. Bristol: Intellect Books.

23. Nelson, N., \& Wright, S. (1995). Participation and Power. In N. Nici \& W. Susan (Eds.), Power and Participatory development: Theory and Practice (pp. 1-18). London: Intermediate Technology Publications.

24. Preston, S. (2009). Introducation to Participation. In T. Prentki \& S. Preston (Eds.), Applied Theatre Reader (pp. 127-129). London: Routledge.

25. Pretty, J. N. (1995). Participatory learning for sustainable agriculture. World Development, 23(8), 1247-1263.

26. Rahman, A. M. (1993). People's SelfDevelopment: Perspectives on Participatory Action Research, a Journey Through Experience. London: Zed Books.

27. Rahnema, M. (1992). Participation. In W. Sachs (Ed.), The Development Dictionary (pp. 116-131). London: Zed Books.

28. Schneider, H., \& Libercier, M. L. (1995). Participatory Development: From Advocacy to Action. Paris: OECD. 
29. Hinthorne, L. L., \& Schneider, K. (2012). Playing with purpose: using serious play to enhance participatory development communication. International Journal of Communication, 6, 24.

30. Kincaid, D. L., \& Figueroa, M. E. (2009). Communication for participatory development: Dialogue, action, and change. In L. R. Frey \& K. N. Cissna (Eds.), Routledge handbook of applied communication research (pp. 506-531). Abingdon, UK: Routledge.

31. Reeves, L. S. (2015). Visualizing Participatory Development Communication in Social Change Processes: Challenging the Notion that Visual Research Methods are Inherently Participatory. International Journal of Communication, 9, 33273346.

32. Beltrán, S. (1979). Farewell to Aristotle: horizontal communication.

33. Heimann, R. B. (2006). Thermal spraying of biomaterials. Surface and Coatings Technology, 201(5), 2012-2019.

34. Donais, T. (2009). Empowerment or imposition? Dilemmas of local ownership in post-conflict peacebuilding processes. Peace and Change, 34(3), 3-26.

35. Chambers, R. (1995). Paradigm Shifts and the Practice of Participatory Research and Development. In N. Nelson \& W. Susan (Eds.), Power and Participatory development: Theory and Practice (pp. 30-42). London: Intermediate Technology Publications.

36. Manyozo, L. (2012). Media, Communication and Development: Three Approaches. New Delhi: Sage Publications India Pvt Ltd.

37. Plastow, J. (2010). Karibuni Wanachi: Theatre for Development in Tanzania, by Julie Koch, and Theatre for development in Kenya: In Search of an effective Procedure and Methodology, By Christopher J Odhiambo. Research in Africa Literatures, 41(1), 182-184.

38. Sloman, A. (2011). Using participatory theatre in international community development. Community Development Journal, Advance Ac, 1-16.

39. Chinyowa, K. C. (2015). Participation as 'repressive myth': a case study of the Interactive Themba Theatre Organisation in South Africa. Research in Drama Education: The Journal of Applied Theatre and Performance, 20(1 March), 37-41.

40. Rahnema, M. (2009). Participation. In P. Tim, Prentki; Sheila (Ed.), Applied Theatre Reader (pp.
141-147). New York: Routledge.

41. Doho, G. (2008). Theatre and Environmental Education in Cameroon by John Taku Takem; Women in Theatre for Development in Cameroon : Participation , Contributions and Limitations by Emelda Ngufor Samba. Research in Africa Literatures, 39(2), 166-169.

42. Odhiambo, C. J. (2005). Theatre for development in Kenya: interrogating the ethics of practice Theatre for development in Kenya: interrogating the ethics of practice 1. Research in Drama Education: The Journal of Applied Theatre and Performance, 10(2), 189-199.

43. Clifford, S., \& Hermann, A. (1999). Making a Leap: Theatre of Empowerment: A Practical Hand book for Creative Drama Work with young People. London: Jessica Kingsly Publshers.

44. Chinyowa, K. C. (2005). Manifestations of Play as Aesthetic in African Theatre for Development. PhD Thesis, Griffith University. Retrieved from https://www120.secure.griffith.edu.au/rch/items/5 00e9e9e-e843-f2bb-c535-d18bbc927506/1/

45. Freire, P. (2009). The Pedagogy of the Oppressed. In Prentki, Tim \& S. Preston (Eds.), The Applied Theatre Reader (pp. 310-313). London: Routledge.

46. Byam, D. L. (1999). Communities in Motion: Theatre for Development in Africa. Westport: Bergin and Garvey.

47. Ledwith, M. (2005). Community Development: A Critical Approach. Bristol: The policy Press University of Bristol.

48. Fox, J. (2009). Playback Theatre in Burundi: Can Theatre Transcend the Gap? In S. Prentki, Tim; Preston (Ed.), Applied Theatre Reader (pp. 241248). London, UK: Routledge.

49. Isgren, E. (2012). Participatory agricultural development in practice - the case of the Nnindye project. Swedish University of Science: Masters Thesis.

50. Darder, A. (2003). Critical Pedagogy: An Introduction. In A. Darder \& Et-al (Eds.), critical Pedagogy Reader (pp. 1-24). New York: Routledge Falmer.

51. Blackburn, J. (2000). Understanding Paulo Freire: Reflections on the origins, concepts, and possible pitfalls of his educational approach. Community Development Journal, 35, 1-15.

52. Melkote, R. S., \& Steeves, L. H. (2001). Communication for Development in the Third World: Theory and practice for Empowerment. Mohan, India: Sage Publication. 